\title{
INDIGENOUS AUSTRALIANS AND LEGAL EDUCATION: LOOKING TO THE FUTURE
}

\author{
HEATHER DOUGLAS*
}

Indigenous ${ }^{1}$ people are under-represented in the Australian legal community. Some Law Schools have attempted to address the issue by increasing the opportunities for Indigenous students to obtain places in law schools. However, the high attrition rates among Indigenous students continue to undermine the efforts of these Law Schools ${ }^{2}$ While providing increased access to Indigenous students is an important starting point, the continued high rates of attrition highlights the fact that addressing access issues is not in itself sufficient. If law schools provide alternative entry programs to Indigenous students they must also provide a system of support for those students. In order to give Indigenous students the opportunity to succeed, formal access issues must be tackled at the same time as the more substantive issues of on-going support. The Pearce Report notes that experience in law schools has shown that merely to admit Indigenous students without more is unsatisfactory. ${ }^{3}$ This is reinforcd by experience in American Universities which suggests that special admission programs have resulted in high attrition rates where the students are left unsupported after entry ${ }^{4}$

In most Australian law schools affirmative action programs in relation to access are an integral part of the university. ${ }^{5}$ and the focus in Australia has gradually shifted from emphasising access issues to improving success rates in students' studies through on-going support programs. ${ }^{6}$

The objectives of this article are twofold. The first objective is to discuss the theoretical justifications for structural and institutional reforms that may be needed to improve legal education for Indigenous Australians. ${ }^{7}$

Secondly, this article aims to identify the steps that might be taken by law schools to improve opportunities for access and to reduce attrition rates for Indigenous law students. The relevant steps may be classified as structural (such as pre-law programs and tutorial support) or institutional (for example, curriculum initiatives). ${ }^{8}$

\section{BARRIERS TO ACCESS AND SUCCESS}

There are clearly many barriers to be negotiated by Indigenous students in order to first obtain access to, and then succeed at law school. These barriers are inter-linked: low socio-economic background, lack of formal education, language difficulties, a perception by Indigenous people that law schools are not places for them and cultural differences, including ways of understanding what law means.

\section{a) Poverty}

It is widely recognised that Indigenous Australians make-up a disproportionate number of members of the community who are in receipt of social security payments and who live in poverty. ${ }^{9}$ This is likely to lead to a lower standard of education and diminish the opportunities for access to and success at law school. Clearly if students from a low socio-economic background gain access to law schools they will be burdened with financially related stresses which are likely to make success much more difficult to attain. ${ }^{10}$ Expenses associated with everyday living will be difficult to manage, buying text books and coping with costs such as photo-copying may be impossible. Moreover, insecurity in housing, created for example, by month to month tenancies and hostel type accommodation, may result from financial difficulties and again cause 
added stresses whilst students are searching for suitable accommodation. ${ }^{11}$

\section{b) School}

Poor education is another barrier to access to and success at law school. The Aboriginal Education Report points out that approximately $40 \%$ of Indigenous 17 year olds were attending formal education in 1991 as compared to a $75 \%$ participation rate for other Australians. ${ }^{12}$

One problem that may impact on Indigenous students is that it is often difficult to attract teachers to Aboriginal communities which may cause students' educations to be disrupted. Associated with this concern, is the difficulty of attracting appropriately trained teachers. The Aboriginal Education Report has recommended that more Indigenous people be trained to teach Indigenous students and that nonIndigenous people who are to be placed at Aboriginal schools be appropriately trained. ${ }^{13}$ A recent South Australian study noted that Indigenous students in remote communities have few of the "more general support mechanisms taken for granted by urban students (e.g. secondary schools, libraries and comprehensive health and community services)." ${ }^{14}$ Similar educational disadvantages have been noted in Canada, ${ }^{15}$ and the rate of successful school completion for Native Americans remains at one quarter the National average. ${ }^{16}$ Poorer education at high school and primary levels leads to a correspondingly poor representation of Indigenous people at tertiary levels. In 1991 only 7\% of Indigenous people were studying at tertiary level; compared with a rate for the entire Australian population of around $25 \% .{ }^{17}$

\section{c) Perceptions}

The perception of law students or potential law students that law schools are not places for them or that they are too hard to get into or get through may be a barrier for some Indigenous people. Hamlar points out that minority students are not usually from a family or a community where they know lawyers, she suggests that familiarity with lawyers can enhance the education process. ${ }^{18}$ Hamlar's views are supported by a study conducted in New South Wales which found that about $50 \%$ of lawyers have legally qualified relatives. ${ }^{19}$ This familiarity is likely to demystify law and law school, ease the transition into tertiary education and assist the student to develop confidence. A lack of confidence can be a dominant cause of students' academic problems. ${ }^{20}$ Indigenous students at the University of New South Wales Law School have suggested that role-models are an important contributor to success. ${ }^{21}$ The lack of role-models and the resulting loss of confidence clearly forms a barrier to both access and success.

The responsibility of being a role-model may be difficult. At the same time as a student's position as a role-model makes them necessary to their particular community, it also suggests their inferiority in the broader community. ${ }^{22}$ Another problem may be that students feel disempowered by the experience of being a role-model, for example; does the student want to be a role-model? Sharon Venne, an Indigenous Canadian lawyer was a role-model for other members of her tribe and felt immense pressure as a result of acting as a role-model. ${ }^{23}$ Indigenous students have found the experience of being a role model highly motivating. ${ }^{24}$

The perception of feeling out of place in law school is emphasised by the fact that Indigenous students make up a very small proportion of law school students. The experience in Canada has been that the universities who already attract more First Nations continue to do so, creating a snow-balling effect. ${ }^{25}$

\section{d) Negative experience}

For many Indigenous people, law is a negative factor in their lives either directly through personal experience or indirectly through the experiences of family or community members. This is supported by the fact that Indigenous people make up $1.5 \%$ of the population and $14.65 \%$ of the prison population. ${ }^{26}$ This negative view of law may be another factor discouraging Indigenous people from wanting to pursue law studies. 


\section{e) Language}

Another problem that confronts Indigenous people is that for many English is the second language. A number of Indigenous people speak a language other than English at home. ${ }^{27}$ Furthermore the kind of English spoken at home may differ markedly from the type spoken at home by most of the other students at law school. A Canadian study found that students who spoke a "Native language" as a first language were less likely to succeed. ${ }^{28}$

Most students have difficulty with the language used at law school. Many cultural assumptions form an important part of the legal language if both the assumptions and the language have to be learned the study of law is a much more difficult task. Indeed, an Indigenous student at the University of New South Wales Law School said, “The language is a problem. They're using words that even an educated blackfella hasn't heard. And assumed knowledge is a problem with the lecturers. ${ }^{30}$

\section{f) Cultural difference}

Cultural difference represents a major barrier for many Indigenous students. Many of the barriers already discussed could be described broadly as cultural difference. The teaching of Common Law in Australian law schools involves the teaching of lineal relationships between parties, for example the doctrine of privity in contract law. This understanding of law is quite a different perception of law to that held by most Indigenous Australians. Indigenous people, although not homogenous, have a more holistic notion of law, more circular than linear, “... law is about relationships ... a serious life and death business for individuals and for the world, it tells how the world hangs together" ${ }^{31}$ Parallels can be drawn to the Canadian First Nation peoples view of law, according to Canadian Professor Leroy Little Bear; "Many Native people think in terms of cyclicity. This is not a straight line. It is a circle ... This philosophy is a result of a direct relationship to the acrocosm. The sun is round; a day is a cycle ... A characteristic of cyclical thinking is that it is holistic, in the same way that a circle is whole ...”32

The oral history tradition of Australian Indigenous people is also at odds with the Law School experience. As Patricia Monture points out, institutionalised education requires truth to be located "outside ourselves" and it is inappropriate "to footnote the knowledge that my grand-mother told me". ${ }^{33}$

Feminist literature has raised concerns in relation to the way law is taught to women, suggesting that the approach has traditionally been one which excludes women, they are treated as outsiders. ${ }^{34}$ Womens' experiences, to some extent, become irrelevant, so that the learning experience can become repressive. In a similar way, the experiences of Indigenous people can become marginalised and the learning experience similarly repressed. Monture describes the feeling of being not only a woman but a First Nation woman as being "layered like an onion" 35 in an attempt to point out that there is a complex relationship between race and gender so that being a woman of color is a particular experience of marginalisation. McKinnon suggests that law is written from the standpoint of men's experience. ${ }^{36}$ Perhaps one could add white men's experience to demonstrate the extent of its traditional exclusiveness. This aspect of law must be recognised by the teacher if he/she is to teach minority groups effectively. Perhaps most important of all is a re-focus on the way in which law is taught in law schools. Specifically, in relation to teaching Indigenous people "truly inquiring forms of learning" should be this may include sharing leadership in the classroom, developing co-operative structures, and fostering an environment of mutual respect. ${ }^{38}$ This approach is likely to benefit all students.

The issue of the cultural appropriateness of mainstream education was recognised by the Aboriginal Education Report which noted that there may be a tension between what is "equitable" and what is "appropriate". ${ }^{39}$ On the one hand non-Indigenous people in the community raised a concern that existing forms of education are not reaching Indigenous people. On the other hand, there is a concern that existing forms of education are not relevant or are inappropriate to Indigenous people, a concern raised by many members of the Indigenous community. The Report suggests that these tensions can be reconciled if "goals relating to 'equitable and appropriate outcomes' are interpreted to mean that Aboriginal and Torres Strait Islander students and communities should have at least as good a chance of achieving their own goals as others have of achieving the goals that they choose." ${ }^{\prime 40}$ The consequence of this tension is that law schools must take responsibility, not only to allow Indigenous students greater access, but also to provide 
curriculum that is meaningful to Indigenous participants. Behrendt suggests that the curriculum must provide something which will connect to the student's point of view and that it must accommodate different voices in order to allow this connection. ${ }^{41}$

Questions which need to be posed by law schools might include: Do the existing course offerings meet the requirements of the Aboriginal community for education? How are the demands of the Aboriginal community to be identified? Who should meet those demands? In response to recommendation 212 of the RCIADIC, ${ }^{42}$ legal curriculum has been developed at TAFE and tertiary level for Aboriginal field officers. Development has occurred in consultation with Aboriginal Legal Services and the resulting material aims to be culturally appropriate. ${ }^{43}$ The courses place an emphasis on flexibility especially with regard to entry into and exit from courses. ${ }^{44}$

\section{WHY SHOULD LAW SCHOOLS MAKE AN EFFORT TO ATTRACT AND RETAIN INDIGENOUS}

\section{LAW STUDENTS?}

Many recent government reports have commented that Australian law schools should be graduating more Indigenous students. ${ }^{45}$ It appears that generally this is seen as a good thing: but why?

There are three basic theories to justify special admission processes to minorities. ${ }^{46}$ These are reparation, social utility and distributive justice. The literature in relation to Indigenous students' education and support tends to focus on arguments of social utility and distributive justice.

Reparation is the repairing of damage caused by historical discrimination. Reparation is probably one of the underlying principles in the preparedness of Australian society to accommodate Indigenous concerns. ${ }^{47}$

Social utility arguments suggest that there are social benefits for all in including minorities in the mainstream. Four sub-arguments can be advanced; that Indigenous lawyers will provide more appropriate services to their community, that law school diversity is positive for all students, that Indigenous students can act as role models for those in the minority community, and finally that Indigenous law students can help to eliminate negative stereotypes that inhibit minority participation in community life. ${ }^{48}$

Weisbrot's study ${ }^{49}$ of the background of Australian lawyers discovered that most were educated at selective private schools, had conservative political affiliations and were from high socio-economic backgrounds. Clearly, in Australia, the profession remains relatively homogenous. Homogeneity may not be a good thing, it encourages intolerance and ignorance. ${ }^{50}$ Indeed, Patricia Monture argues that her concern is "not only for what I lost [in the law school experience] but for what my colleagues lose as a result of a unicultural legal experience. Diversity is a source of inspiration ... or should be ... for all of us.”51

MacAulay argues that First Nation lawyers are more likely to work in areas related to First Nation

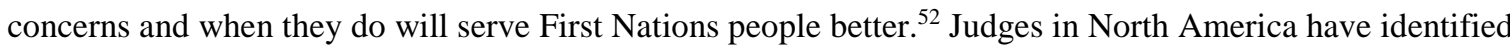
the positive nature of injecting diversity into the Law School experience, suggesting a broader range of experience is a better thing for all. ${ }^{53}$ Role models' existence will have a domino effect and increase chances of success, encouraging students by their presence, not only to commence studies but also motivate them to continue.

Distributive justice is about sharing wealth and opportunity between all citizens of a nation. Distributive justice includes concepts of fairness and justice. The idea of equality is embedded in the Australian psyche. ${ }^{54}$ The rule of law is the lynch pin of our notion of what justice is, and affirmative action programs can transform the formal idea of equality in to substance and reality. The word equality generates different ideas, the Special Advisory Committee to the Canadian Association of Law Teachers (SACCALT) suggested that there are two concepts of equality, the liberal concept of equality and the more "proactive differentiated concept of equality". 55

In 1918 Max Weber noted that the lawyer "has played an incomparably greater, and often even dominant, role as a professional politician”. ${ }^{66}$ If we look at those with political power many are Law graduates, clearly the legal profession offers a good starting point for power. This situation is mirrored in Canada where the relationship between law and politics is also very strong. ${ }^{57}$ It is precisely because of the power that the study of law can provide that more Indigenous people should be graduating from Law School. These notions are echoed by the SACCALT who found that the legal profession holds an unusual concentration of economic and political power and as a result it is the community's responsibility to ensure 
equality in legal education. ${ }^{58}$

\section{AFFIRMATIVE ACTION}

Patricia Williams, a black American law professor, writes that affirmative action is “... an act of verification and of vision. It is an act of social as well as professional responsibility." ${ }^{59}$

Affirmative action measures with respect to access to education have recently been challenged in the United States. In Hopwood v State of Texas ${ }^{60}$ the court held that preferential admission to university for blacks and Mexican Americans was contrary to the constitutional protection of equality before the law. In this case four white people were denied admission to the University of Texas, they would have been admitted had they been black or Mexican American. The white complainants argued that the practice of special admission violated their constitutional rights. The lower court judge found that although the applicants' rights had been violated, no order would be made in relation to the University's admission policy. ${ }^{61}$ The lower court judgment was strongly criticised as "entrenching racial preferences as part of our political and legal culture." ${ }^{2}$ In reviewing this decision, the higher court found that "[i]n sum, the law school failed to show a compelling state interest in remedying the present effects of past discrimination sufficient to maintain the use of race in its admissions system." ${ }^{33}$ The court found that using the preferential admissions system was not admissible to either increase the diversity of the student population or as a device to remedy past discrimination.

What then is the situation is Australia? Section 8 of the Racial Discrimination Act 1975 (Cth) [RDA] ${ }^{64}$ allows for "special measures", or affirmative action while section 10 of the RDA attempts to establish formal equality. In 1985 the case of Gerhardy v Brown ${ }^{65}$ section 8 of the RDA. The Pitjatjanjara Land Rights Act 1981 (SA) vests a large area of land in central Australia in the Pitjatjanjara people. NonPitjatjanjarans have to have permission to enter onto the land. When Brown entered onto the land without permission, he was charged with an offence. Brown argued that the South Australian Act was contrary to the RDA. ${ }^{66}$ However, the court held that the South Australian Act was valid as a special measure pursuant to section 8 of the RDA, this meant that some of the judges did not feel obliged to discuss the question of whether the South Australian legislation was discriminatory pursuant to the RDA. Both Gibbs CJ and Brennan J found that if the South Australian act had not been a "special measure", it would have been inconsistent with the RDA. ${ }^{67}$

Sadurski comments that the decision of Gerhardy $v$ Brown is "both encouraging and disappointing" ${ }^{68}$ Encouraging because it allowed an affirmative action measure, disappointing because it failed to engage in any serious discussion of the meaning of discrimination. Having said this Mason $\mathrm{J}$ comes close to attempting to define discrimination when he suggests that the drafter of section 10 of the RDA "seems to have had his focus on discrimination against a particular race - the obvious case - rather than on discrimination in favour of a particular race." ${ }^{\circ 9}$ Sadurski suggests that the courts failure to discuss "the substantive indicia of discrimination" and what are "legitimate non-discriminatory racial distinctions" has to do "with the institutional and ideological structure of Anglo-Australian law which is particularly reluctant to spell out any substantive moral judgements of distributive justice."70

While Hopwood v State of Texas and Gerhardy v Brown lend support to a notion of formal equality (or the liberal kind of equality, which assumes that everyone is equal), there is opposition to this way of viewing equality. ${ }^{71}$ Kymlicka argues that "the historical domination of some groups by other groups has left a trail of barriers and prejudices that makes it difficult for historically disadvantaged groups to participate effectively ...." ${ }^{72} \mathrm{He}$ is speaking of the political process but his comments could easily be applied to issues of access and success in education for minority groups. Current views of reparation in Australia may also impact on the way equality is perceived. Cullen suggests that, for the judiciary, there is "a moral presence of the past" and that this "shaped the Court's approach to the legal problems they confronted in Mabo 1992". ${ }^{73}$ This provides support for the proactive differentiated concept of equality that access programs and, as importantly on-going support programs attempt to satisfy.

\section{THE CANADIAN STORY}

Indigenous Canadians are more likely than their Australian counterparts to hold a tertiary degree and yet 
they are still less than half as likely as the general Canadian population to hold a tertiary degree. ${ }^{74}$ Of the fourteen Common law Schools in Canada, several have developed special entry and/or ongoing support programs for Native Canadians. ${ }^{75}$

\section{a) Recruitment}

Some Canadian Universities have a strong focus on the recruitment of students.

Given the difficulties Indigenous students face in gaining entry to Law School, active recruitment can be a good way of attracting students to the discipline. Considering the suggestion previously outlined, that Indigenous students have difficulty perceiving themselves as Law students and therefore are not attracted to apply, recruitment is particularly relevant. The University of British Columbia (UBC) has the highest enrolment of Indigenous students. ${ }^{76}$ This is partly due to an emphasis on recruitment, earlier in the university's history, this included UBC representatives attending at high schools, colleges, and meeting with parents and educators. As UBC attracted more Indigenous students, recruitment has become less active and word of mouth has become more important in attracting students. This again relates back to the "snowballing" effect outlined previously. Word of mouth is perhaps a key way to draw students to a course especially amongst Indigenes with varying cultural backgrounds. According to Purich, word of mouth takes time so, attracting students must be a long-term project. ${ }^{77}$ Results, in terms of greater enrolment, may not manifest themselves for some years after the recruiting process has commenced. In spite of the much larger numbers of Indigenous Canadian law graduates, recruiting remains a fairly active process at universities in Canada. ${ }^{78}$ It is suggested that the Native community should be involved in the recruitment process, this can be done through the setting up of advisory committees or through Indigenous Law Centres within the university. ${ }^{79}$ MacAulay suggests that Law Schools will need to "reach out to Native communities in an active and on-going manner until there are much greater numbers of Indigenous graduates. ${ }^{80}$

\section{b) Entry}

Generally entry to law School in Canada is based on the Law School Admissions Test (LSAT) and undergraduate results. Thus, when Canadian students get to Law School, they have usually completed an undergraduate degree. As Clark points out, law school is the only means of access to the legal profession so "equality of opportunity without sacrifice of standards must be the touchstone of socially responsible admission policies" ${ }^{81}$ Most Canadian Universities have now developed alternative entry routes for First Nation students. Much of the literature is quick to point out that special admissions criteria is nothing new, noting that alternative access also exists for mature-aged students and disabled students among others. ${ }^{82}$ Generally the criteria considered include age, education, work-experience and personal interview. ${ }^{83}$ Many universities actually set aside a certain number of positions for First Nations people. Many Indigenous Canadian students will apply for entry to law school, having already undertaken some tertiary study and although this may not be a requirement for alternative entry, there is some suggestion that students who have previous University experience are more likely to succeed. ${ }^{84}$ This is clearly different to the usual entry to law school for Australian students, where most students are studying at tertiary level for the first time when they commence law school. ${ }^{85}$

\section{C) Pre-Law Programs}

Until 1990, the University of Saskatchewan was the only Canadian university to offer a pre-law program, it has the largest intake of Indigenous students and is the most established program in Canada. In 1973 the Law School of the University of Saskatchewan began offering its Program of Legal Studies for Native people. ${ }^{86}$ The course is open to Native Canadians resident in Canada. The administrators of the course work with other university law schools in Canada to ensure that students applying for the pre-law course can gain conditional entry to the university they wish to attend. Entry to the relevant university is conditional on satisfactory completion of the Saskatchewan pre-law program. The course is intensive and runs over an eight week period. The students are taught in both lecture and tutorial format. Since its beginning there has been a good deal of experimentation with curriculum. In 1988 the focus changed dramatically, from learning substantive law to skills-based learning. The skills taught are divided into two 
areas, base skills and legal skills. Base-skills stressed in the course include critical reading, study strategies and writing. Legal skills refer to identifying issues, facts and arguments, synthesising material, evaluating argument and applying law to new situations. ${ }^{87}$ The current course is dense and is designed to reflect the typical first year experience. It includes practice exams, preparation and presentation of a moot case, legal writing and research.

Before the course started there were about four "active" First Nation lawyers, in 1982 there were seventy-five, fifty five of whom completed the pre-law program at Saskatchewan university ${ }^{88}$ As of 1989 there were 118 graduates of the Saskatchewan pre-law program who had successfully graduated from law schools in Canada. ${ }^{89}$ It would seem that the pre-law program has had a great impact on increasing the number of First Nation Law graduates.

Due to its association with other Canadian universities the program is able to draw on teaching assistance from universities all over Canada. The course is flexible enough to be able to respond to the needs of the individual students. ${ }^{90}$ For example, if students are identified as having language difficulties, particular assistance can be given in relation to literacy. One-to-one tutorial assistance is also provided to students, probably another advantage of having a large pool of staff and resources to draw on. Five subjects are taught in the course: Legal writing and Indian Law, Contracts, Torts, Property and Criminal Law.

The results obtained by students at the end of the course are based on their likelihood of coping with the study of law. Depending on the assessment the student receives a recommendation is made as to whether a student should be admitted to first year law studies. Almost always, if a student is recommended they will be accepted to the school where they obtained conditional entry.

Dalhousie University, Canada's oldest Common-law University, has recently commenced a pre-law program for Indigenous Blacks and Micmacs (the IBM). The program runs over four weeks. The first intake took place in the Summer of 1990 and accepted ten students. ${ }^{91}$ Successful applicants to the IBM have the opportunity to continue with studies at Dalhousie where a place in the Law School is assured. The program has the advantage of being able to draw on the experience of the Saskatchewan program and some of its staff have previously been involved with the Saskatchewan program. ${ }^{92}$ Ottawa University has also recently offered a Pre- Droit Program. ${ }^{93}$

\section{d) On-going support}

After completion of the Saskatchewan program, most students go to universities other than Saskatchewan. The universities who accept Saskatchewan pre-law program graduates have different programs in place for on-going support. Monture suggests that four law schools deserve special mention: Dalhousie, Alberta, UBC and Ottawa. ${ }^{94}$ Support provided includes tutorial programs, the appointment of Race Relations Officers, and the setting up of First Nations or community advisory committees. Given the financial difficulties of many Indigenous students, scholarships would be useful, however only one University provides this assistance. ${ }^{95}$ In a more general sense, Monture suggests that offering Aboriginal rights courses in the mainstream curricula can have a more broadly based impact by making the law school a less alien environment. ${ }^{96}$ This is something that is being taken up in Australia.

\section{THE AUSTRALIAN SCENE}

Australian law schools began to change their approaches to Indigenous legal education in the early 1990s. ${ }^{97}$ The situation in Australia is dynamic and it would be difficult to discuss all the types of support offered by all the Australian law schools. Some existing support programs are mentioned below.

\section{a) Recruitment}

In an attempt to attract Indigenous students to law school, some universities have developed a range of publicity materials such as brochures and posters. ${ }^{98}$ Indigenous education units within universities have traditionally taken an active role in publicising Indigenous law programs. To a large degree Australian programs rely on "word of mouth" and this appears to be an effective way to attract Indigenous students.

The University of New South Wales (UNSW) program for Indigenous students appears to provide a 
good example of the "snow-balling" effect previously mentioned. The numbers of Indigenous students enrolling in the program have continued to grow steadily as more students move up through the program. ${ }^{99}$

\section{b) Entry}

Most Australian University law schools offer alternative access procedures to Indigenous students. This is based generally along similar lines to the Canadian requirements: including age, success at studies, previous work-experience, connection to the Indigenous community, amount of and availability of support networks. Lavery's research indicated that nine of eighteen law schools surveyed in 1990 had special entrance provisions for indigenous students. ${ }^{100}$ Some Australian universities specify a number of places for Indigenous students. ${ }^{101}$

Monash University runs the Monash Orientation Scheme for Aborigines (MOSA). Various programs are offered as part of the scheme. The scheme was praised by the Pearce Report as one of only two universities offering successful support programs at the time. ${ }^{102}$ The scheme offers a one year bridging course for Indigenous students. The bridging course is general in nature and provides an introduction to both science and humanities. The course has two major aims. The first aim is to give Indigenous students the opportunity to improve skills: the students are taught problem solving techniques and how to write exams and essays. The second aim of the course is to introduce students to new areas of study and therefore to provide them with an opportunity to find out what interests they have with respect to further study. Students who complete the bridging course can apply for a place in the Monash Law School.

The discretionary admissions policy at the UNSW emphasises the need "for applicants to be able to demonstrate academic skills, most often they have recently completed the Higher School Certificate, the University Preparation Program, or some other tertiary study." 103

\section{C) Pre-law programs}

In 1991 the Australian Law Teachers Association (ALTA) conference took place in Perth. There was a strong attendance, and many university law schools were represented. Lavery's research was presented at the Perth conference. At the end of the conference a resolution was passed that the establishment of an intensive pre-law program at one or more law schools should be supported. ${ }^{104}$

The 1992 meeting of the Australasian Law Deans passed a resolution supporting holding a National Seminar at James Cook University in Queensland, to consider the establishment of a pre-law program. At this 1992 meeting a second resolution was passed welcoming the support of James Cook University to convene a National Seminar on Aborigines and Torres Strait Islander Peoples and Legal Studies and expressing support for the initiative. ${ }^{105}$

The 1992 meeting resolutions inspired the arranging of the 1993 Cairns National Conference on Aborigines and Torres Strait Islands Peoples and Legal Studies. The eventual establishment of several prelaw programs in Australia can be attributed in part to the enthusiasm generated by the 1993 conference. About 40 people attended the Cairns meeting representing 12 law schools, Aboriginal University Support units and Aboriginal Legal Service organisations. The general idea developed in the meeting was to set up a six week pre-law program modelled on the Saskatchewan program, based at James Cook University, to take place over the summer university vacation. Like the Saskatchewan program, the emphasis would be on skills. The plan was for a regional program, other universities would accept certificates of satisfactory completion and could refer inter-state students to the program. ${ }^{106}$ Ultimately this did not occur, ${ }^{107}$ however there were some very positive outcomes including the setting up of several Indigenous support programs in law schools around Australia.

There are now several available alternatives for Indigenous students who want to attend a pre-law course. The number is growing rapidly, it would be impossible to outline all the available programs, I will overview some examples.

Murdoch University and the University of Western Australia currently run a joint program in Western Australia. ${ }^{108}$ (Between 1994 and 1996 this program was run in conjunction with the Northern Territory University.) The 1994 program accepted seventeen students, twelve of whom were assessed as being 
capable of succeeding at law school. ${ }^{109}$ In 1995, twenty-one students attended the program. Fifteen of those students received recommendations for law schools. ${ }^{110}$ The program focused on three subject areas: Legal System; Contract Law and Criminal Law. The course is clearly modelled on the Saskatchewan program with a focus on skills, specifically legal research and writing skills and provides assessment of students at the end of the course on the basis of their likelihood of succeeding at law school. Students who are assessed as likely to succeed can attend either of the participating law schools. The program runs for five weeks over the summer vacation. Although the program is open to all students, it has a limited admission of 22 students. ${ }^{111}$

By far the most successful university to date in relation to numbers of Indigenous graduates of law is the UNSW. ${ }^{112}$ This success is most likely related to several factors including: a continued commitment to access and support to Indigenous students; the development of the Aboriginal Law Centre; and the snowballing affect discussed previously.

In 1995, the UNSW offered its first pre-law program, 11 people enrolled and ten completed the course. ${ }^{113}$ Twenty students attended the pre-law program in $1996 .{ }^{114}$ The course is similar to the WA/NT program, the UNSW program is however not regional in focus, all Indigenous students who apply to take part in the pre-law program are accepted into both the pre-law program and unconditionally into the law course at UNSW. This position perhaps reflects the concern that setting up a sub-quota for Indigenous students may be seen as displacing other highly qualified students and may "provoke a backlash and charges of racial discrimination". ${ }^{115}$

In 1996 UNSW received a grant ${ }^{116}$ to make a series of videos for use in pre-law programs and as a learning aid for Indigenous students during the first year of law school. The videos feature Aboriginal law students. Some of the footage that has been developed is that of first year law lectures in progress at various universities, it is designed to provide students with a greater understanding of what to expect from law school.

If Indigenous people are accepted into the law course at Monash through the MOSA bridging course, they are then required to complete a pre-law program which is also run by MOSA. The pre-law program runs between two and five days. This time frame is flexible, the larger the number of students the longer the program. ${ }^{117}$ In 1995 the program accepted five students and in 1996, two students. Like other pre-law programs discussed in this paper the course focuses on skills including exam technique and problem solving. The course places some emphasis on understanding legal language, using informal discussion. Students are required to sit a test at the end of the course which they must pass to be assured of a place in the law school. The pre-law course is specific to Monash law school, it is not recognised by other law schools. The current pre-law program co-ordinator aims to establish a regional prelaw program for Victoria, along the lines of the WA/Murdoch program. This has some support from other universities. ${ }^{118}$

\section{d) On-going support}

The Aboriginal Law Centre was originally set up in 1981 at the UNSW ${ }^{119}$ as a support centre for the Aboriginal Law Bulletin ${ }^{120}$ but its role has continued to expand. ${ }^{121}$ The existence of the Centre at the University indicates to Indigenous students the importance with which Aboriginal issues are treated and this helps to motivate students to continue their studies. ${ }^{122}$ In 1987 the University established the Aboriginal Student Centre which provides a permanent meeting place for students, the centre has been important to the students, first, because it facilitates student networking and second, because of the availability of resources such as computers. ${ }^{123}$

The UNSW law school teaches a subject, at both undergraduate and masters level, which focuses on Aborigines and the law. ${ }^{124}$ This demonstrates an awareness by the law school of the issues particularly relevant to Indigenous students and aims to make the law school environment less alienating for Indigenous students. More generally, UNSW has a commitment to the inclusion of material relating to Indigenous issues in the main-stream curriculum. As Le Brun and Johnstone point out, an alienating educational environment can have a "chilling" effect on students. ${ }^{125}$ Clearly the main emphasis at UNSW is on making the whole law school learning environment more inclusive and perhaps this is why the school is proving so successful in respect of the education of Indigenous students.

Griffith Law School has developed a "Mentoring Program". In this program Indigenous students are 
paired with practising solicitors. This program recognises that most Indigenous law students do not personally know lawyers. The aim of this program is to give Indigenous students the opportunity of making connections with solicitors in the workplace, developing an understanding of what lawyers do thus breaking down the perception students may have of being alienated from the legal profession. Most Universities that provide pre-law programs also provide extra tutorial support on either a needs basis or at regular intervals.

\section{WHERE TO NOW?}

\section{a) Poverty}

This may be difficult for law schools to address beyond the provision of scholarships. Law firms may be willing to provide some financial aid to students. Assistance for the purchase of textbooks can be of great benefit to students. Some Indigenous education centres provide copies of textbooks for communal use, computer resources and can assist students to obtain financial relief. ${ }^{126}$

\section{b) School}

To some extent education issues can be addressed by pre-law programs as outlined above. Australian universities should be encouraged to provide pre-law courses or access to such courses to Indigenous students. Access would be better provided if law schools combined resources to provide pre-law courses. It is probably the case, for example, that the Brisbane area Universities could offer one course between them. If that were to occur there would be more students attending the course which would provide a better reflection of the first year mainstream law school experience. A joint program would also have the benefit of introducing participating students to a broader network of Indigenous law students. Acting together in the manner of the WA Universities would also mean that more staff would be likely to be available to teach in such a program, this would take pressure off teachers who are mostly attempting to run entire courses with little assistance and also improve the standard of teaching. Overall, the pooling of resources is likely to create a superior program.

Programs should be run over at least four weeks so that the students individual strengths and weaknesses can be discovered and if necessary, addressed. Four weeks (as a minimum) also allows the students to develop relationships with each other which can assist in creating a support network for on-going study.

\section{c) Perceptions and negative experience}

Although many law schools have alternative access programs in place, in many cases Indigenous students are still not being attracted in the numbers which may be expected. Recruitment should be an important focus for law schools to become involved in. There have been several successful recruitment programs developed in America which attempt to identify potential law school candidates at college leve1. ${ }^{127}$ Such programs attempt to assist students to develop skills whilst still in college so that the necessary skills are well developed by the time the students get to law school. It would be possible for Australian law schools to target students whilst attending high school and provide them with information, some skills training and encouragement in the later years of high school. Some recruitment could be done within universities across disciplines. Culturally appropriate material and methods should be used to promote such programs, this may include personal visits to students at their schools and brochures and posters with Indigenous input in relation to design. Advice from Indigenous Education Units should be sought for assistance and advice.

\section{e) Language}

Indigenous students who come to a law school from a background where English is not always spoken or is not a first language are likely to find law school difficult. Pre-law programs can address these issues to some extent. This shows the importance of having a longer pre-law program so that problems with reading and writing can be properly identified and individual assistance can be arranged. There is clearly a limit to what law schools can achieve in this area. 


\section{f) Cultural difference}

Nettheim suggests that one of the major reasons Indigenous students are not successful at law school is social alienation. ${ }^{128}$ Law schools need to work to counter this. Indigenous Higher Education Centres in law schools may assist to emphasise the presence and respect for Indigenous people. A separate space for Indigenous students can help, as can the visible evidence of respect for Indigenous culture, such as the display of Aboriginal art, and the availability of Aboriginal resource material in the library. The development of sensitive curriculum is also important, not only in the form of separate subjects focusing on Indigenous issues but also to make certain that all existing subjects reflect the fact of Indigenous people in Australia. ${ }^{129}$

\section{CONCLUSION}

UNSW recently evaluated their Indigenous support programs and found that the gradually increasing support services for Indigenous law students has corresponded with an increasing number of students receiving credits or above in their assessment, while subject failure rates have fallen. The retention rate has improved to around $60 \% .{ }^{130}$ In most law schools it is still too early to say whether the programs outlined above have been successful.

The issue of legal education for Indigenous people is not going to go away, Indigenous population in Australia will continue to increase. ${ }^{131}$ The current Australian government would appear to have recognised the need to improve educational outcomes for Indigenous Australians. The Minister for Education, Senator Amanda Vanstone said recently: "If Indigenous people are to achieve real social, economic and political equality in all walks of Australian life, it is imperative that our universities become fairer places and more attuned to the needs of Indigenous Australians. ${ }^{132}$ The 1996 budget has committed $\$ 6.5$ million to the establishment of a number of specialist Indigenous Higher Education Centres in various areas. One of those areas is law. ${ }^{133}$ It is not clear who will be involved in making decisions about this money or how this money will be spent but it may mean that some law schools will be in a position to set up support programs for Indigenous law students. It is important for law schools to engage in careful planning in relation to Indigenous legal education. Access remains important but the key focus should be on the implementation of programs which foster the success of Indigenous students. Inextricably linked to this is a concentration on finding ways to reduce the attrition rates of these students.

The Aboriginal Education Report recommends the need for self determination in education for Indigenous people, which means "putting the authority to make decisions in the hands of Aboriginal people and Torres Strait Islanders". ${ }^{134}$ Whatever steps are taken by law schools, programs for Indigenous students must reflect the aims and needs of the Indigenous community, this requires careful consultation with those on whom such programs will impact.

* Associate Lecturer, Faculty of Law, Griffith University. The writer wishes to thank Brad Sherman and Marlene Le Brun for their advice and assistance and to Carolyn Penfold for her support. My interest in this area arises from my work with Indigenous first year law students at Griffith University. I am mindful of Hugh MacAulay's need to point out an important caveat that he, like myself, is white "with all the biases and ignorance that that may entail”: Improving Access to Legal Education for Native People in Canada (1991) 14 Dalhousie LJ 133, at 134.

(C)1997. (1996) 7 Legal Educ Rev 225.

1 When using the term Indigenous Australian the author is referring to Australian Aboriginal and Torres Strait Islander people.

2 The attrition rate of Indigenous law students is probably around 75\%. D Lavery, The Participation of Indigenous Australians in Legal Education (1993) 4 Legal Educ Rev 177, at 182.

3 Commonwealth Tertiary Education Commission, Australian Law Schools: A Discipline Assessment for the Commonwealth Tertiary Education Commission (Pearce Report) (Canberra: AGPS, 1984) vol 2, at para 12.18.

4 P Hamlar, Minority Tokenism in American Law Schools (1983) 26 How LJ 443, at 532

5 Lavery, supra note 2, at 180.

6 Success refers to passing and therefore being eligible to move onto the next year of the course or gain a degree. Lavery notes that "there is increasing access to the law schools for Aboriginal and Torres Strait Islander students", supra note 2, at 181. Since that article was written a number of law schools have developed pre-law programs. Some of these initiatives are discussed later in this article.

7 This essentially involves the application of a theoretical structure set out by Hampden (concerning North America) to the Australian position. B Hampden, Preparing Undergraduate Minorities for the Law School Experience (1989) 12 Seton Hall Legis J 207, at 209.

8 The methodology adopted for achieving this is essentially a review of literature in relation to the Australian, North American and Canadian experiences in relation to the legal education of Indigenous Australians, Native Americans and First Nations respectively. 
The Australian and Canadian experience shares a similar historical development in respect of Indigenous people, thus there will be more focus on the Canadian situation.

9 Amongst young people unemployment may be as high as 5\%, Commissioner E Johnston QC, Royal Commission into Aboriginal Deaths in Custody (RCIADIC) (Canberra: AGPS, 1991) vol 1, at 409.

10 A Dalhousie University report found that a major reason for attrition in relation to Indigenous students has been a lack of money: MacAulay, supra note *, at 141.

11 Of the Indigenous Australian students studying first year law at Griffith Law School, six of eight are in receipt of social security and five of eight had moved house within the first quarter of the year. Information from interviews with Griffith University first year law students conducted by the writer in 1996.

12 R Fujii et al, National Review of Education for Aboriginal and Torres Strait Islander People (Aboriginal Education Report) (Canberra: AGPS, 1995) Final Report, at 76.

13 Id at $41-45$

14 E Ramsay, D Tranter, R Sumner, \& S Barrett, Outcomes of a University’s Flexible Admissions Policies (Canberra: AGPS, 1996) 34.

15 MacAulay, supra note *, at 142.

16 D Purich, Affirmative Action in Canadian Law Schools: The Native Student in Law School (1986) 51 Saskatchewan L Rev 79, at 82.

17 Australian Bureau of Statistics, Report on Australia's Aboriginal and Torres Strait Islander Population (Canberra: AGPS 1993) 35 (figure based on 1991 census).

18 Hamlar, supra note 4, at 535.

19 D Weisbrot, Recent Statistical Trends in Australian Legal Education (1991) 2 Legal Educ Rev 219, at 235.

20 Hamlar, supra note 4, at 536. For a contrary argument, see L Taylor, Factors that Effect Academic Success in Law School (Unpublished Thesis: Bond University Law Library, 1996).

21 C Penfold, Indigenous Students' Perceptions of Factors Contributing to Successful Law Studies (1996) 7 Legal Educ Rev 155, at 166-168. See also P Monture, Now That The Door is Open: First Nations and the Law School Experience (1990) 15 Queens LJ 179, at 200 (referred to as Door open). Patricia Monture, a Native Canadian lawyer, speaks of the lack of numbers of other First Nation students when she attended law school as intensifying the feelings of alienation and isolation she felt.

22 M Le Brun, \& R Johnstone, The Quiet (R)evolution: Improving Student Learning in Law (Sydney: Law Book Company, 1994) 114.

23 S Vennue, Issues of Concern to Indigenous Women as Proposed at the World Conference on Women in Beijing, China, paper presented at the Women and the Law Interest Group, Australian Law Teachers Association Conference, Flinders University, 12 July 1996.

24 Griffith University Law School, Indigenous First Year student, 1996.

25 Purich, supra note 16 , at 85.

26 D Biles, Deaths In Custody (Canberra: AGPS, 1992) 91. The Canadian experience in this regard has been similar where a First Nation person is three times as likely to be imprisoned, Purich, supra note 16, at 84 .

27 RCIADIC, supra note 9, vol 2 at 411, according to the 1986 census almost 6\% of Indigenous people have limited English proficiency.

28 MacAulay, supra note *, at 139.

29 For example, the notion of the 'reasonable' person, and the defining of 'social' and 'commercial' in relation to the intention to be legally bound in a contract.

30 Penfold, supra note 21, at 157.

31 D Bird-Ross, Dingo Makes us Human (Cambridge: Cambridge University Press 1992) 44.

32 L Little Bear, Concept of Native Title (1982) 2 Canadian Legal Aid Bull 99; see also R Strickland, American Indian Law and The Spirit World (1973) 1 Am Indian L Rev 33, at 34, who writes that the Chemkee world-view is about consensus and harmony rather then dispute and confrontation.

33 P Monture-O’Kanee, The Roles and Responsibilities of Aboriginal Women: Reclaiming Justice (1992) 56 Saskatchewan L Rev, 237, at 240 .

34 T Alvi et al, Equality in Legal Education: Sharing a Vision, Creating Pathways (1993) 17 Queens LJ 174, at 194.

35 Monture, “Door open”, supra note 21, at 207. See also L Whiu, Feminist Legal Theorising and the Diverse Experiences of Women (1994) 2 Waikato L Rev 8.

36 C MacKinnon, Feminism in Legal Education (1989) 1 Legal Educ Rev 85, at 87.

37 C Menkel-Meadow, Feminist Legal Theory, Critical Legal Studies and Legal Education or "The FemCrits Go To Law School" (1988) $38 \mathrm{~J}$ Legal Educ 61, at 77.

38 M J Mossman, Gender Issues in Teaching Methods: Reflections on Shifting the Paradigm (1995) 6 Legal Educ Rev 129, at 135,139 .

39 Aboriginal Education Report, supra note 12, at 83.

40 ld at 83 .

41 L Behrendt, Womens Work: The Inclusion of the Voice of Aboriginal Women (1995) 6 Legal Educ Rev 169 , at 172.

42 RCIADIC, supra note 9. Recommendation 212 encourages the effective dissemination of information about anti-discrimination legislation.

43 Aboriginal and Torres Strait Islander Commission, Third Annual Report 1995: Aboriginal and Torres Strait Islander Social Justice Commissioner (Canberra: AGPS, 1995) 146.

44 D Barker, Qualifying Aboriginal and Torres Strait Islander Field Officers: An Effective Anti-Discrimination Mechanism?, paper presented at the Indigenous People and the Law Interest Group, Australian Law Teachers Association Conference, Flinders University, 12 July 1996

45 RCIADIC, supra note 9, recommendation 299(b); Australian Law Reform Commission, Multiculturalism and the Law: Australian Law Reform Commission Report No. 57 (Multiculturalism and the Law) (Canberra: AGPS, 1992) 8; The Pearce Report, supra note 3; Aboriginal Education Report, supra note 12, Summary and Recommendations at 2. 
46 B Hampden, Preparing Undergraduate Minority Students for the Law School Experience (1989) 12 Seton Hall Legis J 207, at 209.

47 Cullen argues that a recognition of the brutal history of Australia in relation to Indigenous people was an underlying influence for the judges in Mabo in finding a Native Title right for the Meriam people. R Cullen, Rights to Offshore Resources After Mabo 1992 and the Native Title Act 1993 (Cth) (1996) 18 Sydney L Rev 125, at 150.

48 K Greenawalt, Discrimination and Reverse Discrimination (New York: Cambridge University Press, 1983) 59.

49 Weisbrot, supra note 19, at 227.

50 Multiculturalism and The Law, supra note 45, at para 1.1. The Australian government's objectives in relation to multiculturalism at the time of requesting this report included the promotion of "an environment that is tolerant and accepting of cultural and social diversity ...”. See also para 1.38 .

51 Monture “Door open”, supra note 21, at 201.

52 MacAulay, supra note *, at 137.

53 C Finke, Affirmative Action in Law School Academic Support Programs (1989) 39 J Legal Educ 55, at 59.

541997 is the International Bar Association Year of the Rule of Law.

55 Alvi et al, supra note 35, at 177.

56 M Weber, Essays in Sociology (New York: Routlege Kegan Paul, 1982) 85.

57 MacAulay, supra note *, at 135.

58 Alvi et al, supra note 34, at 178.

59 P Williams, The Alchemy of Race and Rights: Diary of a Law Professor (Massachusetts: Harvard University Press, 1991) 50.

60 Hopwood $v$ State of Texas, 95 F3rd 53 (5th Cir, 1996).

61 Hopwood $v$ State of Texas, 861 F Supp 551 (W.D. Tex 1994).

62 L Graglia, Hopwood v Texas: Racial Preferences in Higher Education Upheld and Endorsed (1995) 45 J Legal Educ 79.

63 Hopwood $v$ State of Texas, 861 F Supp 551 (W.D. Tex 1994).

64 This Act is based on the International Convention on the Elimination of all Forms of Racial Discrimination.

65 Gerhardy v Brown (1985) 159 CLR 70.

66 N O’Neill, \& R Handley, Retreat From Injustice: Human Rights In Australian Law (Leichardt: Federation Press, 1994$) 389$.

67 Gerhardy v Brown (1985) 159 CLR 70, 82, 123.

68 W Sadurski, Gerhardy v Brown v The Concept of Discrimination: Reflections on the Landmark Case That Wasn't (1986) 11 Sydney L Rev, 5.

69 Gerhardy v Brown (1985) 159 CLR 70,100-101.

70 Sadurski, supra note 68, at 7-8. See also M Thornton The Liberal Promise: Anti-Discrimination Law in Australia (Melbourne: Oxford University Press, 1990) 224: "Out of deference to the canons of statutory interpretation and the rule of law, the Court has not been prepared to acknowledge that race-conscious distinctions are other than exceptions to the non-discrimination principle.”

71 S Bottomley, N Gunningham, \& S Parker, Law In Context (Maryborough: Federation Press, 1994) 20-23 and also M Thornton, Dissonance and Distrust: Women in the Legal Profession (Melbourne: Oxford University Press, 1996) 37-38.

72 W Kymlicka, Multicultural Citizenship: A Liberal Theory of Minority Rights (New York: Oxford University Press, 1995$) 141$.

73 Cullen, supra note 47, at 150.

74 Monture, “Door open”, supra note 21, at 179.

75 Id at 200.

76 MacAulay, supra note *, at 147.

77 Purich, supra note 16, at 91.

78 Monture, “Door open”, supra note 21, at 197. In 1990 five Canadian Law Schools had recruitment programs in place and two others were planning them.

79 Id at 198.

80 MacAulay, supra note *, at 148.

81 D Clark, Legal education in Saskatchewan: The Last Ten Years (1983) 7 Dalhousie LJ 375, at 378.

82 R Carter, University of Saskatchewan Program of Legal Studies for Native People (1980) 4 Canadian Community LJ 28, at 32; MacAulay, supra note *, at 148; Purich, supra note 16, at 86.

83 Purich, supra note 16 , at 92.

84 Id at 93.

85 Penfold notes that "By far the majority of students come into the law school directly from the Higher School Certificate." C Penfold, Supporting Aboriginal Students Through Transition to University - A Law School Experience (UNSW Experience) (Unpublished: University of New South Wales, 1995) 1.

86 R Carter, The University of Saskatchewan Native Law Centre (1979) 44 Saskatchewan L Rev 135. Roger Carter was the Dean of Saskatchewan University Law School in 1973 and developed the pre-law program along the limes of the program developed by Sam Deloria at the University of New Mexico. There is very little published information available about the University of New Mexico Program.

87 J Broocke, Skills Based Tutorials (Saskatchewan: University of Saskatchewan, Native Law Centre, 1990) 7.

88 Clark, supra note 81, at 382.

89 MacAulay, supra note *, at 149.

90 Purich, supra note 16 , at 94.

91 Lavery, supra note 2, at 190.

92 MacAulay, supra note *, at 150.

93 Lavery, supra note 2, at 190.

94 Monture, “Door open”, supra note 22, at 198.

95 Id at 200. 
96 Id at 198.

97 The major published research in relation to the Australian situation is Daniel Lavery's article Indigenous Australians and Legal Education which relates to research carried out in 1990. Lavery, supra note 2.

98 For example, UNSW and UWA.

99 C Penfold, Support for Indigenous Students in the Faculty of law, University of New South Wales, 1989-1995 (Unpublished: UNSW, 1996) 8.

${ }^{100}$ Lavery, supra note 2, at 181.

${ }^{101}$ Griffith University Law School offers a maximum of 10 places through its alternative entry program. This is related to the teaching resources which are available for support.

102 The Pearce Report, supra note 3, at para 12.19. The other university was UNSW.

103 Penfold, supra note 99, at 3. The "University Preparation Program" is a part time study skills program to prepare students for university generally.

104 Annual General Meeting of Australian Law Teachers Association (ALTA), Perth, WA, 14 July 1991.

105 National Conference on Aboriginal and Torres Strait Islander Peoples and Legal Studies Conference Notes, Cairns Hilton, 15-19 February 1993 (National Conference Notes) 1.

106 Id at 5.

107 There are probably several reasons for this, including the difficulty of involving such a large group of interested people and the physical distance between the organisers.

${ }^{108}$ R Bartlett, The Aboriginal Pre-Law Programme (Western Australia and Northern Territory), Report on Implementation of the Project, Unpublished, 1995, University of Western Australia, 2.

109 R Bartlett, Legal Education: The Aboriginal Pre-Law Program (WA and NT) (1994) 19 Alternative LJ 141.

110 Bartlett, supra note 108, at 10, 11.

111 The NT, WA and Murdoch Universities program publicity material as at 1996.

112 Penfold, supra note 21. As at 1995, 23 Indigenous people had graduated from UNSW Law School.

113 UNSW Media Release, 19 October 1995.

114 Penfold, supra note 99, at 7.

${ }^{115}$ G Nettheim, What Australian Law Schools Can Do To Enhance the Participation and Graduation Rates of Indigenous Australians, paper presented at the Cairns conference, 15 February 1993, at 1.

${ }^{116}$ National Teaching Development Grant, funded by the committee previously known as Committee for the Advancement of University Teaching (now known as the Committee for University teaching and Staff Development), Department of Employment, Education and Training.

${ }^{117}$ The program may run for up to ten days. The program is made longer if more students attend on the basis that if there is a larger group more debate and discussion is possible.

118 Discussion with Joan Kimm, pre-law program coordinator, Monash University, 19 August 1996.

119 Garth Nettheim played an important role in the establishment of the Aboriginal Law Centre.

120 Published monthly.

121 The Centre now also publishes the Aboriginal Law Reporter on a quarterly basis.

122 Penfold, supra note 21, at 162-166.

123 Id at 162.

${ }^{124}$ Nettheim, McRae and Beacroft Co-wrote “Aboriginal Legal Issues” as the text for the course. The text has subsequently been used by many law schools. G Nettheim, H McRae, \& R Beacroft Aboriginal Legal Issues (Sydney: Law Book Company, 1997).

125 Le Brun, \& Johnstone, supra note 23, at 65.

${ }^{126}$ For example the Gumurrii Centre at Griffith University.

127 Hampden, supra note 40, at 212.

128 Nettheim, supra note 116 , at 3.

129 MacAulay, supra note 1, at 139.

130 Penfold, supra note 100 , at 9

131 Aboriginal and Torres Strait Islander Commission, Social Justice For Indigenous Australians (Canberra: AGPS, 1995$) 12$.

132 DEETYA Media Release, V62/96 August 1996, available on-line, http://www.deet.gov.au/hed.

133 Id.

134 Aboriginal Education Report, supra note 13, at 27. 